of film shows ; the first consisted of films taken in Sarawak and presented with a lively running commentary by Tom Harrisson (Sarawak), while the second included films taken in New Guinea and presented personally by L. G. Brongersma (Holland), one taken in North Borneo and presented personally by I. Polunin (Singapore), and one by the Malayan Film Unit, which was introduced by R. D. Purchon (Singapore).

The British Council prepared a photographic exhibition of Darwiniana specially for the Congress, and this was displayed in the Art Museum of the University of Malaya, where it was the object of considerable interest. The exhibition was afterwards displayed in Kuala Lumpur and, so that the maximum benefit should be gained from its preparation, it was then sent on tour; part was sent to Colombo for the meeting of the Ceylon Association for the Advancement of Science and the remainder was sent first to Kuala Lumpur and then to Bangkok. On its return it will be presented to the Department of Zoology, University of Malaya, through the generosity of the British Council.

A bibliographic exhibition was organized by the Foreign Service of the United States and consisted of about three hundred biological publications the majority of which were sent from America specially for the Congress, and the greater part of which has been most generously presented to the library of the University of Malaya. This exhibition was augmented by a smaller number of British works, loaned for the occasion by the Singapore agents of various British publishing houses.

After the Congress, an excursion lasting a fortnight was conducted which traversed the west-coast districts of Malaya as far as Perlis. Special attention was paid to freshwater habitats ; the variety observed ranging from rice-fields to torrent-streams, and from acid blackwaters to limestone pools. In addition, visits were made to the Fish Culture Research Station at Batu Berendam, Malacca (Nature, 183, 287 ; 1959); to the Rubber Research Institute and the Institute for Medical Research at Kuala Lumpur ; and to the Fisheries Department and the Bayan Lepas Experimental Farm at Penang. The opportunity was taken to visit and collect from a number of limestone hills and caves.

The post-Congressional field trip to the King George V National Park in the depths of Pahang brought together nine biologists from four continents, whose interests ranged through taxonomy, zoogeography, ecology and evolution. The base of the party was at Kuala Tahan, where they lived in a lodge of the National Park, with adjacent facilities in the Forest Research Laboratory of the Department of Zoology, University of Malaya. The party spent six days walking and collecting through a number of different types of vegetation. They inspected the pattern of quadrats laid out by the Department of Zoology as a part of its long-term programme of ecological research in the jungle. Valuable suggestions were received from the visiting scientists regarding methods of approach and priorities in this programme.

Arrangements were made for some of the visitors to lecture at Kuala Lumpur in the Federation of Malaya, to widen the impact of the Congress. Prof. J. B. S. Haldane gave the substance of his lecture on natural selection and genetics, previously delivered in Singapore, to a special meeting of the Malayan Nature Society. In addition, the Malayen Scientific Association convened a special meeting, at which $H$. Waring (Australia) discussed the studies, which he had previously presented in Singapore, on the marsupial quokka. H. G. Andrewartha (Australia) described some extremely interesting experiments on mice still in progress in Adelaide. These bear directly on intra-specific elements influencing reproduction and may help to interpret the regulation of population densities. L. G. Brongersma showed and commented on the cine film of his zoological field work in Dutch New Guinea. The visitors saw the forest reserves and the laboratories of the Institute for Medical Research and of the Rubber Research Institute.

The proceedinge of the Congress were covered by the Malayan Film Unit, and it is anticipated that a documentary film will be released in the near future.

Any credit balance remaining in the hands of the chairman of the Organizing Committee will be applied as an endowment to provide a book prize in the University of Malaya as a permanent reminder of this very successful Congress and the events which it honoured. Since the Congress was originally conceived to pay public tribute to the works of Alfred Russel Wallace in Malaysia, it is fitting that this should be known as the 'Wallace Prize'. A few copies of the abstracts of papers and of the programme are available (3s. and $2 s$, respectively, including postage).

The scientific papers will be published in full in book form. Applications for the abstracts and programme and advance orders for the scientific papers should be sent to Prof. R. D. Purchon, Department of Zoology, University of Malaya. $\quad$ R. D. PurchoN

\title{
THE HAFFKINE INSTITUTE, BOMBAY DIAMOND JUBILEE
}

$\mathrm{O}$ N January 10 the Haffkine Institute in Bombay celebrated sixty years of service in medical research. At the opening ceremony, which was attended by scientists from India and from other countries, the President of the Republic of India, Dr. Rajendra Prasad, said that Dr. W.M. W. Haffkine, founder of the Institute, had built up a tradition which the modern scientific world could best honour by emulation. It might have been a coincidence that a scientist born in Russia and trained in France happened to be in India, when he was assigned the urgent task of preventing plague from taking a heavy toll of lives; but, the President continued, it served to illustrate that scientific advance of all types called for international collaboration. The Bombay Health Minister, welcoming the delegates, announced that the Government of India had given Rs. 300,000 for the expansion of the Institute and that the Government of Bombay had decided to create a special fund for its development.

Waldemar Mordecai Wolff Haffkine was born of Jewish parents at Odessa on March 15, 1860. He 
obtained his doctorate in science at the University of Odessa in 1884 and, after working with the physiologist, Moritz Schiff, at Geneva, went to the Pasteur Institute at Paris in 1889 as préparateur. Pasteur had introduced vaccine treatment for fowl cholera, and Haffkine in 1892 developed the first successful vaccine against human cholera. Through the influence of Lord Dufferin, British Ambassador at Paris and former Viceroy of India, Haffkine was sent to Calcutta in 1893. The results of his anti-cholera inoculations were so encouraging that the Government of India in October 1896 transferred him to Bombay, where plague had broken out. Haffkine began work at the Petit Laboratory of Grant Medical College; his accommodation consisted of one room and a corridor, and his staff numbered one clerk and three peons, none of whom knew anything of bacteriological methods and had to be trained by him. $\mathrm{He}_{\mathrm{e}}$ succeeded in preparing a prophylactic plague vaccine from pure cultures, which he proved to be harmless on his own person. Its first trial on a plague-stricken community was made in the Bombay House of Correction at Byculla in January 1897. Of 172 untreated prisoners, twelve developed the disease and six died; of 147 inoculated persons, two contracted plague, but none died. During the season at which the plague was prevalent, up to October 1897, 8,142 inhabitants of Bombay applied for inoculation. In April 1897 Haffkine moved his laboratory to a house on Malabar Hill, and in November made another move to premises in Nepean Sea Road, provided by the municipality.

In the following February the Aga Khan placed at his disposal a large house, Khushru Lodge, in Nesbit Lane, Mazagaon. When orders for the prophylactic vaccine began to pour in from all parts of the world, the laboratory became an Imperial concern, and larger premises had to be found at the Old Government House, Parel. The new laboratory was form. ally opened by the Governor of Bombay, Lord Sandhurst, on August 10, 1899, when Major W. B. Bannerman gave an account of the prophylactic and its action. Three years later Haffkine was appointed director of the Biological Laboratory at Calcutta. He left India in 1916 and lived in retirement at Boulognesur-Seine and at Lausanne, where he died on October 26,1930 , aged seventy. A charming, kindly and enthusiastic personality, an accomplished linguist, and a 'bacteriological wizard', Haffkine never married. He was created C.I.E. in 1917.

In 1925 the Government of Bombay decided to call the bacteriological laboratory at Parel 'The Haffkine Institute' to commemorate the name of its founder (Nature, 116, 551 ; 1925).

To-day, this Institute is the largest research institution of its kind not only in India but also in the East. It has a technical staff of more than one hundred scientists and a subordinate staff of more than five hundred workers, supervized by eight assistant directors and one director, Dr. H. I. Jhala. Its functions are medical research, training of research workers, supply of vital biologieals and diagnostic aids. The vaccine department collaborates with the Plague Committee of the Indian Council of Medical Research in research on plague, and with the World Health Organization in standardization of cholera vaccine. The department of virus diseases acts as a laboratory for an influenza centre in India, in the network of World Health Organization laboratories attached to the World Influenza Centre, London. The Institute is affiliated to the University of Bombay for degrees of M.Sc. and Ph.D. in microbiology, biochemistry, organic chemistry, pharmacology, pathology, bacteriology and zoology. W. R. BETT

\section{UNIVERSITY OF OXFORD TANGANYIKA EXPEDITION}

A PARTY from the University of Oxford, with A the support of the Government of Tanganyika, made a preliminary scientific survey of the KungweMahali Mountains on the eastern shore of Lake Tanganyika (longitude $30^{\circ}$ E., latitude $6^{\circ} \mathrm{S}$.) during July-Oetober 1958.

A herbarium collection was made of the plants of the southern two-thirds of the peninsula by J. G. B. Newbould, T. G. Jefford and B. E. Juniper, of the Botany School, Oxford. This is the first major collection from the area. The material will be assermbled and identified at the Royal Botanic Gardens, Kew, for inclusion in the Flora of East Africa. In addition, live orchids were collected and are now in the orchid houses at Kew. Colour photographs were taken of the principal vegetation zones of the area and of many species of flowering plants.

H. F. Lamprey and A. J. Mence, of the Game Department, Tanganyika, and S. Ulfstrand, of the Zoologiska Institution, Lund, made a collection of birds and small mammals. This includes 305 birds, comprising about 135 species. Another 100 species were identified by sight. Among the birds collected were Campethera taeniolaema and Psalidoprocne chalybea. These records extend considerably the known ranges of these birds. One specimen, a wood. pecker of the genus Campethera, with affinities to $C$. abingoni, fits no described species and still remains to be identified.

Among the small mammals, which are at present being examined at the British Museum, is the second specimen from Tanganyika of the ground squirrel genus Protoxerus.

A survey was also made of the isolated chimpanzee population. When further information is available about the flora, particularly of the forest species, further conclusions may be drawn about the affinities this region has with West Africa. These affinities are already apparent to a certain extent in the records of chimpanzees and Protoxerus.

T. E. Stevens completed a geological survey of the south, centre and west of the Mahali Range. Several interesting geomorphological features were observed and a collection of rock specimens was made which will be examined in the Department of Geology, Oxford.

P. L. Simkin, of the University of Oxford, and A. Roggenkämper, of the University of Bonn, made some preliminary anthropological observations among the Waholoholo of the Mahali Mountains. A census was made of the population of some of the villages south of Mount Kungwe. Studies were also made of 